\title{
A DNA Sequence Containing the Control Sites for the uxaB Gene of Escherichia coli
}

\author{
By CARLOS BLANCO* AND MIREILLE MATA-GILSINGER \\ Laboratoire de Microbiologie, Bâtiment 406, Institut National des Sciences Appliquées de Lyon, \\ 20 Avenue Albert Einstein, 69621 Villeurbanne Cedex, France
}

(Received 7 August 1985 ; revised 14 October 1985)

\begin{abstract}
The nucleotide sequence of a $286 \mathrm{bp}$ fragment containing the $u x a B$ control region of Escherichia coli has been determined. The transcriptional start of the $u x a B$ gene has been located and the promoter signals identified. Various fragments of the $u x a B$ promoter-proximal region were fused in vitro with the $l a c Z$ gene. Results obtained with these fusions indicate that the operatorpromoter sites are located on a $110 \mathrm{bp}$ restriction fragment. The determination of the amino acid sequence of the $\mathrm{NH}_{2}$-terminus of the $u x a B$ gene product revealed that the $u x a B$ gene is not initiated with the AUG codon but with the unusual GTG codon. CRP, the cyclic AMP receptor protein, does not bind to the $u x a B$ control region DNA even though expression of the $u x a B$ gene is sensitive to catabolite repression.
\end{abstract}

\section{INTRODUCTION}

Escherichia coli $\mathrm{K} 12$ can grow on the aldohexuronates D-glucuronate and D-galacturonate, which are metabolized via the Ashwell pathway (Ashwell, 1962). The first steps in the catabolism of galacturonate involve, in order, products of the structural genes exuT, uxaC, uxaB and $u x a A$. These genes form the exu regulon. Their expression is subject to negative control by the ExuR repressor, but UxuR, another repressor of the hexuronate system, has no effect on their expression (Portalier et al., 1980; Ritzenthaler et al., 1983). Their expression is also sensitive to catabolite repression by glucose (Hugouvieux-Cotte-Pattat, 1981). The uxaB gene is located at min 52 on the $E$. coli genome (Bachmann \& Low, 1980) and codes for altronate oxidoreductase, the synthesis of which is induced by galacturonate, tagaturonate and fructuronate (Robert-Baudouy et al., 1974).

The $e x u R$ and $u x u R$ regulatory genes, and the $u x a B$ gene, have been individually cloned into the plasmid vector pBR322 or its derivatives (Ritzenthaler et al., 1981; Ritzenthaler \& MataGilsinger, 1982; Blanco et al., 1983). The regulatory region of $u x a B$ was isolated on a $2.5 \mathrm{~kb}$ $E c o \mathrm{RI}_{1}-E c o \mathrm{RI}_{2}$ fragment (Fig. 1), and it has been shown that $u x a B$ is transcribed from the $E c o \mathrm{RI}_{1}$ towards the $E c o \mathrm{RI}_{2}$ site (Blanco et al., 1983). The purpose of this work was to determine the nucleotide sequence of the $u x a B$ control region and to locate on this sequence the promoter and the operator. The latter were more precisely located by the construction and expression of uxaB-lacZ fusions formed in vitro on plasmid vectors.

\section{METHODS}

Bacterial strains, plasmids and culture media. All the strains were $E$. coli K12 derivatives: HB101, Pro- Leu- Str ${ }^{\mathrm{R}} \mathrm{HsdM}^{-} \mathrm{HsdR}^{-}$EndoI- RecA- LacY- (Boyer \& Roulland-Dussoix, 1969); MCl061,

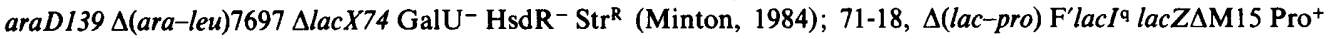
SupE- (Dente et al., 1983); 1475, ExuR- ArgG- HisA- (Portalier et al., 1980).

The lac fusion plasmids pNM480, pMN481 and pMN482 (Minton, 1984) were used for the detection of $u x a B$

Abbreviation: SS-DNA, single-stranded DNA. 
translational initiation signals. Plasmids pEB3 $\left(u x a B^{+}\right)$, pEB7 $\left(u x a B o^{+}\right)\left(B l a n c o\right.$ et al., 1983), pRU101 $\left(u x u R^{+}\right)$and pRE101 (exuR ${ }^{+}$) (Ritzenthaler et al., 1983), are pACYC184 $\left(\right.$tet $^{+}$, cat $^{+}$) derivatives (Chang \& Cohen, 1978); plasmids pEMBL8 and pEMBL9 (Dente et al., 1983) were used for cloning and sequencing $u x a B$ fragments.

Media for growth were identical to those described by Miller (1972). The synthetic medium was M63 (pH 7.2) and contained glycerol $\left(5 \mathrm{~g} \mathrm{l}^{-1}\right)$. When needed, ampicillin and chloramphenicol were used at final concentrations of $25 \mu \mathrm{g} \mathrm{ml}^{-1}$.

Chemicals. D-Galacturonate and $p$-aminobenzyl $\beta$-D-thiogalactosamine agarose were purchased from Sigma, and chloramphenicol and ampicillin from Serva. Purified CRP protein was a gift of B. Blazy. RNA polymerase was obtained from BRL. Fructuronate was synthesized in our laboratory.

Enzyme induction, preparation and assay. The conditions for induction, extraction and assay of altronate oxidoreductase were as outlined previously (Robert-Baudouy et al., 1974; Portalier \& Stoeber, 1972). $\beta$-Galactosidase was assayed by the method of Miller (1972) in exponentially growing cells. All the specific activities reported are the means of at least three separate assays.

Isolation and analysis of plasmid DNA. This was done as described by Blanco et al. (1983) and Maniatis et al. (1982).

3'-labelling of DNA fragments. EcoRI-HindIII fragments purified from pEMBL-E plasmids were 3'-end-labelled with DNA polymerase I Klenow fragment.

Construction of $p E M B L-E$ vectors. The $E c o \mathrm{RI}_{1}-E c o \mathrm{RI}_{2}$ fragment of $\mathrm{pEB} 7$ bearing the regulatory region of the $u x a B$ gene was purified and introduced into the EcoRI site of pEMBL8 in each of the two possible orientations, yielding pEMBL-E1 and pEMBL-E2 (Fig. 1). In pEMBL-E1, the EcoRI ${ }_{2}$ site is located near the lac $Z$ sequence of pEMBL8, whereas in pEMBL-E2 it is EcoRI that is adjacent to lac $Z$. The $E c o \mathrm{RI}_{1}-E c o \mathrm{RI}_{2}$ fragment possesses a unique $N r u$ I site and no $S m a I$ site (Blanco et al., 1983); pEMBL-E1 and -E2 were digested with $N r u I$ and $S m a I$ and ligated in vitro with T4 DNA ligase. The resulting plasmids bearing $N r u I-S m a I$ deletions were named pEMBL-E3 and pEMBL-E4 (Fig. 1).

The purified $E c o \mathrm{RI}_{1}-E c o \mathrm{RI}_{2}$ fragment was digested with $S a u 3 \mathrm{~A}$, and the fragments generated were inserted into the BamHI site of pEMBL8. The pEMBL8 hybrids containing uxaB Sau3A fragments were introduced into strain 71-18 by transformation. Transformant colonies were screened for constitutive altronate oxidoreductase synthesis, since multiple copies of the $u x a B$ operator cause derepression of the $u x a B$ chromosomal gene due to titration out of the ExuR repressor. In clones showing derepression of $u x a B$, the recombinant plasmids contained a unique $200 \mathrm{bp}$ Sau3A fragment. These plasmids were named pEMBL-E5. The $200 \mathrm{bp}$ Sau3A fragment was transferred from pEMBL8 to pEMBL9 using the EcoRI and HindIII sites flanking the pEMBL linker. The resulting plasmid was named pEMBL-E6.

The NruI-HincII (SalI site of pEMBL polylinker) fragment of pEMBL-E5 was deleted, yielding pEMBL-E7; similarly pEMBL-E8 and pEMBL-E9 respectively resulted from the deletion of the HincII fragment of pEMBLE5 and pEMBL-E4.

Construction of $u x a B-l a c$ fusions. EcoRI-HindIII fragments of pEMBL-E were transferred to the vectors pNM480, -481 and -482 , since pNM plasmids possess the same polylinker cloning sites as pEMBL. The resulting pNM vectors were named pNM-E $x$ according to the fragment Ex inserted. Fusions were made in the three reading frames using $\mathrm{pNM} 480,-481$ and -482 . $\beta$-Galactosidase synthesis was obtained only with one of the three pNM vectors.

Sl nuclease mapping. RNA was purified by hot phenol extraction (Salser et al., 1967) from strain 1475 (ExuR-) containing the pEB3 $\left(u x a B^{+}\right)$plasmid. Cells were grown on minimal medium M63 containing glycerol $(0.4 \%$, w/v).

Single-stranded (SS) DNA probes, complementary to the $u \times a B$ sequences cloned into pEMBL-E1 and pEMBLE7, were prepared according to Burke (1984). SS-DNA template was annealed with the universal sequencing primer and the primer was extended with the DNA polymerase I Klenow fragment. After cleavage of the primer at a unique 5' site, the reaction products were denatured, and separated by electrophoresis on acrylamide gels.

RNA $(100 \mu \mathrm{g})$ and SS-DNA probe (100000 c.p.m.) were co-precipitated. The dried pellet of nucleic acids was resuspended in $10 \mu \mathrm{l}$ hybridization buffer $(0.4 \mathrm{M}-\mathrm{NaCl}, 10 \mathrm{mM}-\mathrm{PIPES} \mathrm{pH} 6.5,80 \%, \mathrm{v} / \mathrm{v}$, formamide), incubated for $10 \mathrm{~min}$ at $80^{\circ} \mathrm{C}$ and cooled slowly to $40^{\circ} \mathrm{C}$ overnight. After dilution with 9 vols $\mathrm{S} 1$ nuclease buffer $(0 \cdot 25 \mathrm{M}-\mathrm{NaCl}$, $0.03 \mathrm{M}$-sodium acetate $\mathrm{pH} 4.6,1 \mathrm{mM}-\mathrm{ZnSO}_{4}$ ), unhybridized DNA was digested with S1 nuclease (50 U; BRL) for $30 \mathrm{~min}$ at $37^{\circ} \mathrm{C}$. The ${ }^{32} \mathrm{P}$-labelled SS-DNA products were sized on denaturing sequencing gels $(6 \%, \mathrm{v} / \mathrm{v}$, acrylamide, $8 \mathrm{M}$-urea) alongside a typical DNA sequence.

Purification of $u x a B$-lacZ-encoded protein. Hybrid $\beta$-galactosidase encoded by a $u x a B-l a c Z$ fusion was purified by affinity chromatography, from a culture of strain 1475 containing plasmid pEBG1 (Blanco et al., 1983). Cells were disrupted in a French pressure cell and the mixture was centrifuged at $12000 \mathrm{r} . \mathrm{p} . \mathrm{m}$. for $15 \mathrm{~min}$. The supernatant was made $36 \%$ saturated with ammonium sulphate, and centrifuged at 12000 r.p.m. for $15 \mathrm{~min}$; the resulting pellet was dissolved in buffer $(10 \mathrm{~mm} \cdot$ Tris pH $7,10 \mathrm{~mm}$-magnesium acetate, $0 \cdot 1 \mathrm{M}-\mathrm{NaCl}, 10 \mathrm{mM}-2$ mercaptoethanol), and applied to a $10 \mathrm{ml}$ column of $p$-aminobenzyl $\beta$-D-thiogalactosamine agarose. The eluted 


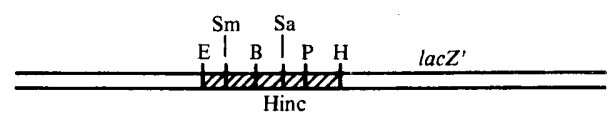

pEMBL8 cloning sites

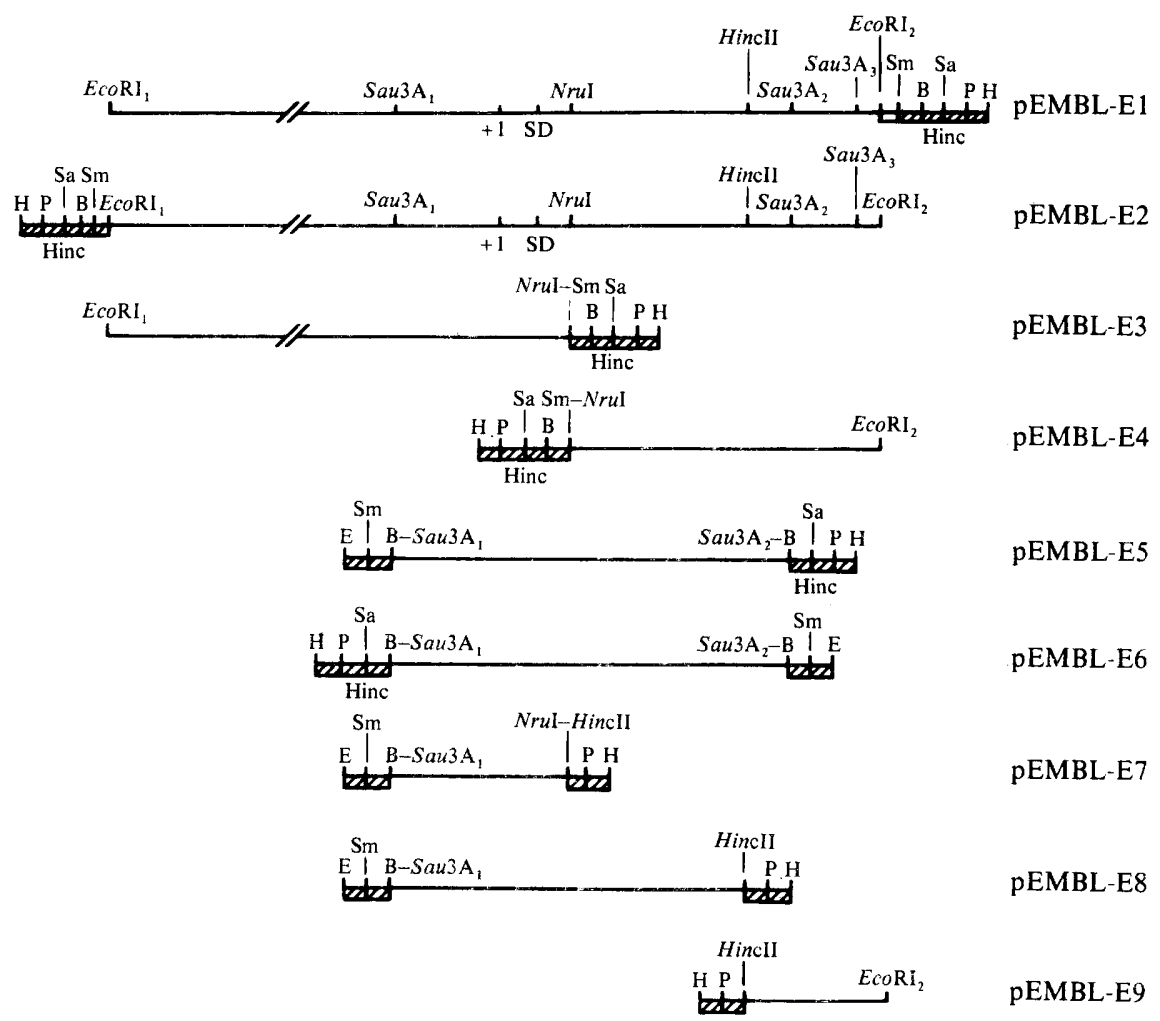

Fig. 1. Structure of the pEMBL-Ex plasmids. See Methods for details of their construction. Only the restriction fragments of the $u x a B$ control region inserted in the plasmids pEMBL are shown (thin lines). These fragments were introduced into $\mathrm{pEMBL}$ opened at one or two of its polylinker sites (hatched areas). E, Sm, B, Sa, Hinc, P and H represent respectively EcoRI, SmaI, BamHI, SaII, HincII, PstI and HindIII polylinker sites of pEMBL8. SD, ribosome-binding site (Shine-Dalgarno sequence); +1 , transcriptional start point of the $u \times a B$ gene.

hybrid $\beta$-galactosidase was repurified on the same column. The purified enzyme was $90 \%$ pure as judged by SDSpolyacrylamide gel electrophoresis. Its $\mathrm{NH}_{2}$-terminal amino acid sequence was determined by J. Bonicel (Service Commun Sequenceur LCB-CBBH, CNRS, Marseille, France).

\section{RESULTS}

Nucleotide sequence of the $u x a B$ regulatory region

The $2.5 \mathrm{~kb} E c o$ RI fragment containing the $u x a B$ regulatory region was purified from pEB7 and cloned into pEMBL-8, in the two orientations, yielding pEMBL-E1 and -E2 (Fig. 1). Various restriction fragments of the $E c o \mathrm{RI}_{1}-E c o \mathrm{RI}_{2}$ segment bearing the entire or part of the $u x a B$ regulatory region were cloned into pEMBL-8 and pEMBL-9, yielding pEMBL-E3 to -E9 (Fig. 1). The SS-DNA of these plasmids was used as template for the determination of the nucleotide sequence of the $u x a B$ control region by the dideoxy chain terminator method of Sanger et al. (1977). Except for the sequence extending from the Sau3 $\mathrm{A}_{1}$ to the EcoRI $\mathrm{R}_{1}$ sites, the nucleotide sequence shown in Fig. 2 was determined several times in both strands according to the various overlaps obtained. 
1

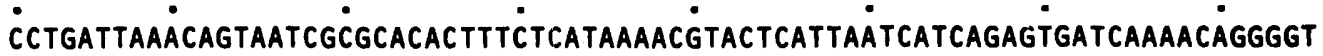

$\Lambda$

$\operatorname{Sau}_{3} \mathrm{~A}_{1}$

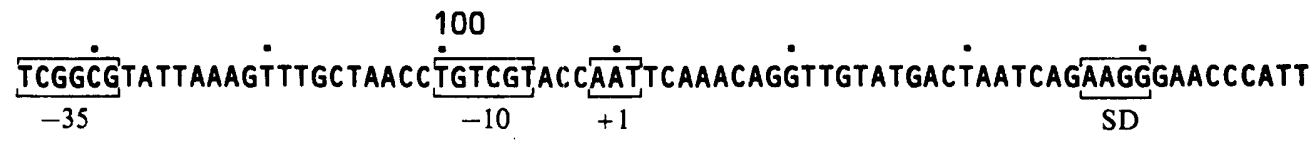

150

GTG AAA ACA CTA AAT CGT CGC GAT TTT CCC GGT GCA CAG TAT CCA GAA CGT ATC
Met Lys Thr Leu Asn Arg Arg Asp Phe Pro Gly Ala Gln Tyr Pro Glu Arg Ile

ATt CAG itt GGT GAA GGT AAC TTC CTG CGC GCC TTT GंTt GAC TGG CAA ATC GAT
Ile Gln Phe Gly Glu Gly Asn Phe leu Arg Ala Phe Val Asp Trp Gln Ile Asp

CTC CTG AAT GAG CAC ACC GAT CTg AAT Tí

Fig. 2. Nucleotide sequence of a $286 \mathrm{bp}$ fragment of the $u x a B$ control region. The proposed -35 and -10 regions of the promoter are boxed. The start point of $u x a B$ transcript (position +1 ) and the ribosome-binding site (SD) are indicated, and the $\mathrm{NH}_{2}$-terminal amino acid sequence of altronate oxidoreductase is shown. Relevant restriction sites are arrowed.

\section{Identification of the transcriptional start of the uxaB gene}

The $5^{\prime}$ end of $u x a B$ messenger RNA was located by S1 nuclease mapping using uniformly labelled SS-DNA probes containing the relevant strand of the DNA fragments. The SS-DNA molecules derived from products of S1 mapping were detected and sized on sequencing gels, in comparison to sequencing ladders derived from pEMBL-E vectors. The $E c o \mathrm{RI}_{1}-\mathrm{NruI}, \mathrm{NruI}-$ $E c o \mathrm{RI}_{2}$ and Sau3A $_{1}-\mathrm{Sau}_{3 \mathrm{~A}_{2}}$ SS-DNA fragments were used as probes for S1 mapping. The $N r u I-E c o I_{2}$ fragment hybridized with mRNA was not cleaved by $S 1$ treatment, showing that the transcription start point is upstream of the NruI site. The sizes of the RNA:DNA hybrid molecules obtained with $E c o \mathrm{RI}_{1}-\mathrm{NruI}$ and $S a u 3 \mathrm{~A}_{1}-S a u 3 \mathrm{~A}_{2}$ were respectively $61 \pm 1 \mathrm{bp}$ and $144 \pm 1 \mathrm{bp}$, indicating that the start point of $u x a B$ transcription is at position $110 \pm 1$ on the nucleotide sequence.

Putative -10 and -35 regions of the $u x a B$ promoter can be identified. The presumptive -10 region, TGTCGT (nucleotides 100 to 105 ), is 18 nucleotides distant from the -35 region, TCGGCG.

\section{Expression and regulation of $u x a B-l a c Z$ fusions}

All fragments cloned on $\mathrm{pEMBL}$ vectors and sequenced were transferred into the fusion probe vectors pNM480, -481 and -482 . These vectors carry the lac operon in which the 
Table 1. Regulation of uxaB-lac $Z$ gene expression

$\beta$-Galactosidase activity is expressed in milliunits [nmol product $\min ^{-1}$ ( $\mathrm{mg}$ dry weight) ${ }^{-1}$ ], and is normalized to a constant level of $\beta$-lactamase activity. All the assays were at $30^{\circ} \mathrm{C}$. The values reported are means of at least three separate assays, results from which varied by $<5 \%$ about the mean. No $\beta$-galactosidase activity was detectable in the presence of the hybrid plasmids pNM-E2, -E4, -E6 or -E9, or that of the parental plasmids pNM-480, -481 and -482 .

Growth medium*

Glycerol

Glucose

Glucose + cAMP (10 mM)

Glycerol

Glycerol

Glycerol + tagaturonate ( $5 \mathrm{mM})$

Glycerol

$\beta$-Galactosidase specific activity* in the presence of:

$\begin{array}{rcccc}\text { pNM-E1 } & \text { pNM-E3 } & \text { pNM-E5 } & \text { pNM-E7 } & \text { pNM-E8 } \\ 1410 & 1980 & 1490 & 4010 & 980 \\ 160 & 190 & 150 & 390 & 70 \\ 1580 & 2240 & 1840 & 4580 & 1010 \\ 1420 & 2020 & 1530 & 4050 & 1080 \\ 20 & 20 & 10 & 30 & 10 \\ 290 & & & 790 & \\ 1450 & 1910 & 1490 & 3820 & \end{array}$

* M63 medium with the additions shown. Glycerol and glucose were used at $5 \mathrm{~g} \mathrm{l}^{-1}$.

regulatory region and the first eight codons of $l a c Z$ have been removed and replaced by the same polylinker cloning sites as in $\mathrm{pEMBL}$. They allow the expression of hybrid $\beta$-galactosidase when a DNA fragment containing transcriptional and translational signals is introduced in the correct orientation in front of the lac genes. The gene fusion can be made in all three translational readings frames using the three vectors pNM480, -481 and -482 . When the inserted fragment contains a promoter but no translational signals, only the lac $Y$ gene is expressed.

Transcriptional and translational signals were examined in the three reading frames by introducing $\mathrm{pNM}$ derivatives into strain MC1061 $(\Delta l a c)$. $\beta$-Galactosidase activity was detected in strain MC1061 containing pNM-E1, pNM-E3, pNM-E5, pNM-E7 and pNM-E8, showing the presence of transcriptional and translational signals in the corresponding DNA fragments. As expected in each case, these signals were only detected with one of the three pNM vectors. All the experiments with the various inserts gave the same result in relation to the translational phase of the $u x a B$ gene. To seek promoter activity in fragments -E2, -E4, -E6 and -E9, pNM vectors bearing appropriate inserts were introduced into $\mathrm{HB} 101\left(\mathrm{LacY}^{-}\right)$. In no case did these plasmids restore a $\mathrm{Lac}^{+}$phenotype to strain $\mathrm{HB} 101$, demonstrating the absence of a promoter activity in the insert fragments.

These results indicated that transcriptional and translational signals are both included in the $110 \mathrm{bp} S a u 3 \mathrm{~A}_{1}-N r u I$ fragment. To prove that these signals belonged to $u \times a B$ gene, the regulation of $\beta$-galactosidase synthesis was analysed in strain MC1061 containing plasmids pACYC184, pRE101 $\left(e x u R^{+}\right)$or pRU101 $\left(u x u R^{+}\right)$in trans to the fusion plasmid. $\beta$-Galactosidase synthesis was specifically repressed upon introduction of pRE101 $\left(e x u R^{+}\right)$; transformation with the control plasmid pACYC184 or with pRU101 $\left(u x u R^{+}\right)$had no effect on the expression of the $u x a B-l a c Z$ gene. The repression exerted by the ExuR regulatory molecule could be reversed upon addition of tagaturonate as inducer (Table 1).

Hugouvieux-Cotte-Pattat (1981) showed that $u x a B$ expression is sensitive to catabolite repression by glucose, which is reversed by cAMP. The $u x a B-l a c$ fusions carried by the pNM vectors were also sensitive to this catabolite repression. $\beta$-Galactosidase synthesis was strongly decreased in cells grown on glucose; when cAMP was added, the $\beta$-galactosidase activity was identical to that observed in glycerol-grown cells (Table 1). The 110 bp Sau3 $\mathrm{A}_{1}-\mathrm{NruI}$ fragment in pNM-E7 was sufficient to confer sensitivity to glucose repression (Table 1). All the regulatory properties of the expression of the $u x a B-l a c Z$ fusions were identical to those observed for the wild-type $u x a B$ gene.

The repression of $\beta$-galactosidase synthesis exerted by the exuR product in strains containing 
Table 2. Expression of $u x a B$ in strain 71-18 containing the plasmids $p E M B L-E 1$ to $-E 9$

Specific activities are given in milliunits [ $\mathrm{nmol}$ product $\mathrm{min}^{-1}(\mathrm{mg} \text { dry weight })^{-1}$ ]. Cells were grown at $37^{\circ} \mathrm{C}$ to an appropriate cell density in glycerol M63 medium with or without inducer and assayed for enzyme activity after treatment in a French press. The induced activities measured in the presence of the plasmids pEMBL-E1 to -E9 were identical to those obtained with the parental plasmid pEMBL8 or 9. The values reported are means of at least three separate assays, results from which varied by $<5 \%$ about the mean.

$\begin{array}{lcc}\text { Plasmid } & \begin{array}{c}\text { Inducer } \\ \text { (galacturonate, 5 mM) }\end{array} & \begin{array}{c}\text { Altronate } \\ \text { oxidoreductase } \\ \text { specific activity }\end{array} \\ \text { pEMBL8 or } 9 & - & 20 \\ \text { pEMBL-E1 } & + & 1010 \\ \text { pEMBL-E2 } & - & 490 \\ \text { pEMBL-E3 } & - & 220 \\ \text { pEMBL-E4 } & - & 390 \\ \text { pEMBL-E5 } & - & 30 \\ \text { pEMBL-E6 } & - & 410 \\ \text { pEMBL-E7 } & - & 380 \\ \text { pEMBL-E8 } & - & 370 \\ \text { pEMBL-E9 } & - & 450 \\ & - & 20\end{array}$

pNM-E7 showed that the 110 bp Sau3 $\mathrm{A}_{1}-\mathrm{NruI}$ segment carries the operator site of $u x a B$. This result was confirmed by the ability of this fragment to titrate out the chromosomal ExuR repressor, leading to constitutive expression of the $u x a B$ gene (Table 2). All the other fragments containing the Sau3 $\mathrm{A}_{1}-\mathrm{NruI}$ segment had the same effect. The level of derepression observed in the presence of pNM-E7 was greater than that obtained in the presence of pEB7, a pACYC184 derivative containing the $E c o \mathrm{RI}_{1}-E c o \mathrm{RI}_{2}$ fragment (Blanco et al., 1983). This difference may be explained by the fact that $\mathrm{pEMBL}$ and $\mathrm{pNM}$ vectors are both $\mathrm{pBR} 322$ derivatives affected for copy number control (Dente et al., 1983; Minton, 1984) as found for pAT153 (Twigg \& Sherratt, 1980), where the copy number is increased 1.5- to 3-fold.

\section{Peptide sequence of the $\mathrm{NH}_{2}$-terminus of altronate oxidoreductase}

An identical reading frame was found for all the $u x a B-l a c Z$ fusions, but no ATG initiator codon could be detected in this reading frame. Fusions performed at the $N r u I$ site led to the expression of a hybrid $\beta$-galactosidase, suggesting that an initiator codon is located upstream of this site. A putative initiator codon GTG at position 160 of the nucleotide sequence is preceded by a good ribosome-binding site AAGG (Shine \& Dalgarno, 1974). To confirm the role of GTG as the initiator codon for the $u x a B$ gene, the amino acid sequence of the $\mathrm{NH}_{2}$-terminus of altronate oxidoreductase was determined. Hybrid $\beta$-galactosidase encoded by the $u \times a B$-lac $Z$ fusion of plasmid pEBG1 was purified to near homogeneity and subjected to Edman degradation. The $\mathrm{NH}_{2}$-terminal sequence determined was $\mathrm{NH}_{2}$-Met-Lys-Thr-Leu, which corresponds to the $\mathrm{NH}_{2}$-terminal sequence of altronate oxidoreductase fused to $\beta$-galactosidase; it is in complete agreement with the codons from nucleotides 150 to 161 . This result shows unambiguously the use of the GTG codon as initiator codon for the $u x a B$ gene.

\section{The $u x a B$ regulatory region has no CRP-binding site}

In most known catabolite-activated operons, principally those involved in the catabolism of growth substrates, the activation is mediated by the catabolite activator protein CRP. In the presence of its effector, cAMP, CRP stimulates the initiation of transcription at the promoter of these genes. Since the $u x a B$ and $u x a B$-lac fusions were sensitive to glucose catabolite repression which was reversed by cAMP, we searched for putative CRP-binding sites in the $u x a B$ sequence. The binding of CRP-cAMP complex to $u x a B$ sequences was tested by the gel electrophoretic method described by Garner \& Revzin (1981), Fried \& Crothers (1983) and Kolb et al. (1983). The binding of proteins to DNA can be easily detected since it alters the electrophoretic mobility of the DNA fragment. The 3'-end-labelled $\operatorname{Sau} 3 \mathrm{~A}_{1}-\operatorname{Sau}_{3} \mathrm{~A}_{2}$ fragment 


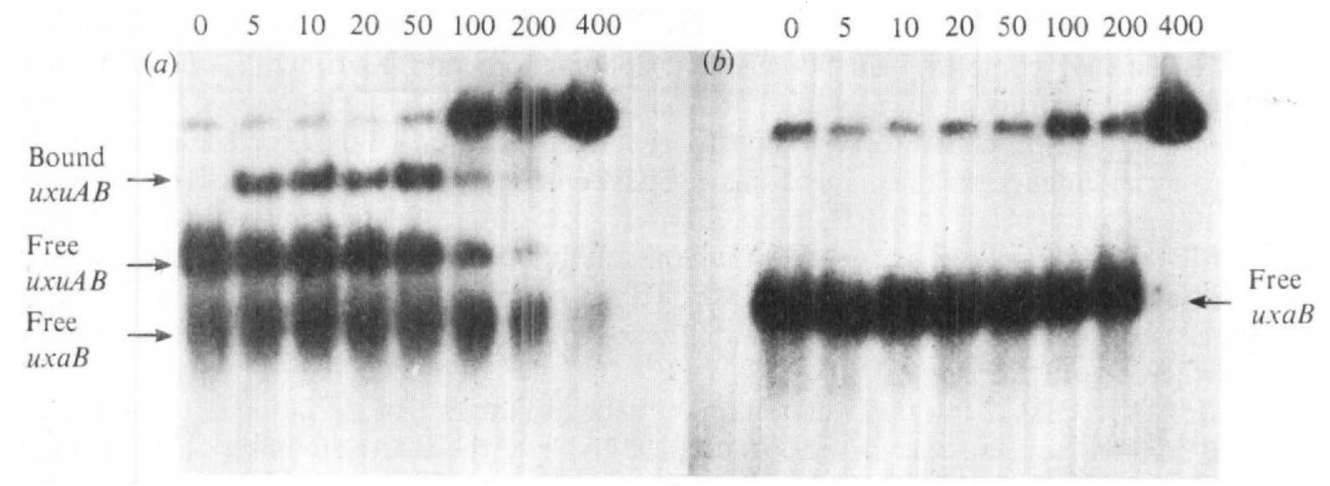

Fig. 3. Test for specific CRP binding to the $u x u A B$ and $u x a B$ promoter regions. Each assay contained $200 \mu \mathrm{M}$-cAMP and from 0 to $400 \mathrm{nM}-\mathrm{CRP}$. (a) Migration of the $u x a B$ Sau3 $\mathrm{A}_{1}-\operatorname{Sau} 3 \mathrm{~A}_{2}$ fragment and of DNA fragments containing the $u x u A B$ control region; (b) migration of the $u x a B S a u 3 \mathrm{~A}_{1}-S_{a u} 3 \mathrm{~A}_{2}$ fragment alone. Each restriction fragment was $3^{\prime}$-end-labelled.

was incubated in the presence of various concentrations of CRP, with $200 \mu \mathrm{M}$-cAMP, and the protein-DNA mixture was submitted to electrophoresis in $8 \%$ polyacrylamide gels. No binding of CRP to the $u x a B$ fragment was found, whereas in the same conditions, an 180 bp DNA fragment containing the $u x U A B C R P$-binding site was displaced in a well-defined band (Fig. 3).

\section{DISCUSSION}

In vitro fusions of $u x a B$ with the $l a c Z$ gene have shown that the entire $u x a B$ control region resides in a 110 bp $S a u 3 A_{1}-N r u$ I DNA fragment, which contains the $u x a B$ promoter, the $u x a B$ operator and the DNA signals necessary for catabolite repression. The nucleotide sequence of the $u x a B$ control region was determined and we tried to locate the various regulatory signals on this sequence. The transcription start was identified at position $110 \pm 1$ on the nucleotide sequence. As regards the mRNA start, the examination of the sequence reveals the presence of -10 and -35 sequences which have poor correspondence with the consensus sequences that have been established for E. coli promoters (Rosenberg \& Court, 1979; Hawley \& McClure, 1983). The Bribnow box is imperfect, and the spacing between these two elements (18 bp) is more than the optimal 17 bp (Hawley \& McClure, 1983; Aoyama et al., 1983). Such features suggest that this putative promoter would show only weak activity. To correlate the high in vivo expression of the $u x a B$ gene or the $u x a B$-lac fusions with this weak promoter sequence we propose an activation mechanism. Physiological and genetic studies have never shown the action of a specific activator for $u x a B$ expression, so we think that such an activator must have a pleiotropic effect, like the CRP-cAMP complex.

The expression of $u x a B$ and $u x a B-l a c$ fusions is sensitive to catabolite repression by glucose, which is reversed by cAMP. The structure of the $u x a B$ promoter is consistent with activation by the CRP-cAMP complex. In fact, examination of the sequences around the transcription start point of CRP-regulated promoters reveal a particularly poor correspondence with the consensus sequences determined for $E$. coli promoters: in most cases the -35 sequence is barely apparent, the Pribnow box is often imperfect, and the spacing between these two elements is more than the optimal 17 bp (De Crombrugghe et al., 1984). Unfortunately no CRP-binding site was detected in the $u x a B$ sequence by alteration of electrophoretic mobility. This result is not surprising since the only putative CRP-binding site, presenting some homology with the consensus sequence AA-TGTGA-N - -CACA (De Crombrugghe et al., 1984), is located at position 149. The highly conserved sequence TGTGA is present, but the location of this putative site downstream of the promoter makes it unlikely that this sequence has a physiological role. We can exclude the possibility of a CRP-binding site being located upstream of the sequenced fragment because the expression of the $u x a B-l a c$ fusion obtained with the $S a u 3 A_{1}-N r u I$ fragment is sensitive to catabolite repression. 
The catabolite repression exerted by glucose on the $u x a B$-lac fusions is possibly not mediated by the CRP-cAMP complex. The inducer exclusion phenomenon (Kornberg et al., 1980) could affect $u x a B$ gene expression in the wild-type strain, but the $u x a B-l a c$ genes carried by multicopy vectors are expressed constitutively, due to repressor titration, thus expression cannot be abolished by an inducer exclusion mechanism. Catabolite repression is not exclusively regulated by the intracellular level of cAMP (Ullman \& Danchin, 1980), it affects lac genes in a $\Delta c y a$ strain (Dessein et al., 1978). So it is possible that the catabolite repression of uxaB-lac fusions is mediated by another effector, possibly CMF (Ullman et al., 1976). The catabolite repression mechanism exerted on $u x a B$ expression, and the existence of an activator for $u x a B$ transcription, need further investigation.

The use of GUG as the initiator codon might decrease the rate of initiation of translation of the $u x a B$ mRNA, as is the case for lacI (Steege, 1977). Nevertheless, the features observed in the DNA sequence of $u x a B$ show that the use of the weak GUG initiator codon is compensated by a good Shine-Dalgerno sequence, by an optimal spacing separating this sequence from the GUG codon, and by the presence of the AAAA sequence following this codon (Kozak, 1983; Stormo et al., 1982; Gheysen et al., 1982). Thus the use of the weak GUG initiator codon for $u x a B$ is compensated by the organization and the nature of the DNA sequence around the initiator codon. The presence of a weak promoter and GUG codon would be expected to lead to low expression of the $u x a B$ gene. In fact, in induced cells (wild-type or containing $u x a B^{+}$plasmids) the $u x a B$ product is synthesized in large amounts, allowing its easy purification (Blanco et al., 1983; Portalier \& Stoeber, 1972).

The operator of the $u x a B$ gene was located to within the $S a u 3 \mathrm{~A}_{1}-N r u$ I fragment. The DNA sequence of this fragment presents some homologies with that of the exuT-uxaCA regulatory region (unpublished observations). We think that the homologous regions are probably the sequence recognized by the ExuR repressor.

This work was supported by grants from the Centre National de la Recherche Scientifique (Laboratoire Propre du CNRS no. UM 380024).

We are indebted to $B$. Blazy for providing purified CRP protein and to $D$. Boxer for reading the manuscript. We thank G. Luthaud for typing the manuscript and C. Van Herrewege for help in the preparation of the illustrations.

\section{REFERENCES}

aoyama, T., Takanami, M., Ohtsuka, E., Taniyama, Y., Marumoto, R., Sato, M. \& IkehaRa, M. (1983). Essential structure of $E$. coli promoter: effect of spacer length between the two consensus sequences on promoter function. Nucleic Acids Research 11, 5855-5864.

AsHWELL, G. (1962). Enzymes of glucuronic and galacturonic acid metabolism in bacteria. Methods in Enzymology 5, 190-208.

BACHMANN, B. J. \& Low, K. B. (1980). Linkage map of Escherichia coli K-12. Microbiological Reviews 44, 156.

Blanco, C., Mata-Gilsinger, M. \& Ritzenthaler, P. (1983). Construction of hybrid plasmids containing the Escherichia coli uxaB gene: analysis of its regulation and direction of transcription. Journal of Bacteriology 153, 747-755.

BOYER, H. W. \& Roulland-Dussoix, D. (1969). A complementation analysis of the restriction and modification of DNA in Escherichia coli. Journal of Molecular Biology 41, 459-472.

BURKE, J. F. (1984). High sensitivity SI mapping with single-stranded [ $\left.{ }^{32} \mathrm{P}\right] \mathrm{DNA}$ probes synthesized from bacteriophage M13mp templates. Gene 30, 63-68.

Chang, A. C. Y. \& Cohen, S. N. (1978). Construction and characterization of amplifiable multicopy DNA cloning vehicles derived from the P15A cryptic miniplasmid. Journal of Bacteriology 134, 1141-1 156.

De Crombrugghe, B., Busby, S. \& BuC, M. (1984). Cyclic AMP receptor protein: role in transcription activation. Science 224, 831-838.

Dente, L., Cesareni, G. \& Cortese, R. (1983). pEMBL: a new family of single-stranded plasmids. Nucleic Acids Research 11, 1645-1655.

Dessein, A., Schwartz, M. \& Ullman, A. (1978). Catabolite repression in Escherichia coli mutants lacking cyclic AMP. Molecular and General Genetics 162, 83-87.

Fried, M. G. \& Crothers, D. M. (1983). CAP and RNA polymerase interactions with the lac promoter: binding stoichiometry and low-range effects. Nucleic Acids Research 11, 141-158.

GARNER, M. \& REvzIN, A. (1981). Gel electrophoresis method for quantifying the binding of proteins to specific DNA regions: application to components of the $E$. coli lactose operon regulatory system. Nucleic Acids Research 9, 3047-3060.

Gheysen, D., Iserentant, D., Derom, C. \& Fiers, W. (1982). Systematic alteration of the nucleotide sequence preceding the translation initiation codon and the effects on bacterial expression of the cloned SV40 small-T-antigen gene. Gene 17, 55-63. 
Hawley, D. K. \& McClure, W. R. (1983). Compilation and analysis of $E$. coli promoter DNA sequences. Nucleic Acids Research 11, 2237-2255.

HugouvieuX-Cotte-Pattat, N. (1981). Etude de la regulation de la voie de degradation des hexuronates chez $E$. coli $K-12$, par analyse de fusion de genes. Thesis, Institut National des Sciences Appliquées de Lyon.

Kolb, A., Spassky, A., Chapon, C., Blazy, B. \& Buc, H. (1983). On the different binding affinities of CRP at the lac, gal and malT promoter regions. Nucleic Acids Research 11, 7833-7852.

KornberG, H., WatTs, P. D. \& Brown, K. (1980). Mechanisms of 'inducer exclusion' by glucose. FEBS Letters 117, K28-K36.

KoZAK, M. (1983). Comparison of initiation of protein synthesis in procaryotes, eucaryotes and organelles. Microbiological Reviews 47, 1-45.

Maniatis, T., Fritsch, E. F. \& SAMbrook, J. (1982). Molecular Cloning, a Laboratory Manual. Cold Spring Harbor, NY: Cold Spring Harbor Laboratory.

MILleR, J. H. (1972), Experiments in Molecular Genetics. Cold Spring Harbor, NY: Cold Spring Harbor Laboratory.

Minton, N. P. (1984). Improved plasmid vectors for the isolation of translational lac gene fusions. Gene 31, 269-273.

PorTalier, R. \& Stoeber, F. (1972). La D-altronate: NAD-oxydoréductase d' $E$. coli $\mathrm{K}-12$ : purification, propriétés et individualité. European Journal of Biochemistry 26, 50-61.

Portalier, R., Robert-Baudouy, J. \& Stoeber, F. (1980). Regulation of Escherichia coli K-12 hexuronate system genes : exu regulon. Journal of Bacteriology 143, 1095-1107.

Ritzenthaler, P. \& MAta-Gilsinger, M. (1982). Use of in vitro gene fusions to study the $u x u R$ regulatory gene in Escherichia coli K-12: direction of transcription and regulation of its expression. Journal of Bacteriology 150, 1040-1047.

RITZENTHALER, P., MATA-Gilsinger, M.\&Stoeber, F. (1981). Molecular cloning of Escherichia coli K-12 hexuronate system genes: exu region. Journal of Bacteriology 145, 181-190.

Ritzenthaler, P., Blanco, C. \& Mata-Gilsinger, M.
(1983). Interchangeability of repressors for the control of the $u x u$ and uid operons in E. coli $\mathrm{K}-12$. Molecular and General Genetics 191, 263-270.

Robert-Baudouy, J., Portalier, R. \& Stoeber, F. (1974). Regulation du métabolisme des hexuronates chez $E$. coli K-12: modalités de l'induction des enzymes du système hexuronate. European Journal of Biochemistry 43, 1-15.

ROSENBERG, M. \& CourT, D. (1979). Regulatory sequences involved in the promotion and termination of RNA transcription. Annual Review of Genetics 13, 319-353.

Salser, W., Gestland, R. \& Bolle, A. (1967). In vitro synthesis of bacteriophage lysozyme. Nature, London 215, 588-591.

Sanger, F., Nicklen, S. \& Coulson, A. R. (1977). DNA sequencing with chain-terminating inhibitors. Proceedings of the National Academy of Sciences of the United States of America 74, 5463-5467.

Shine, J. \& Dalgarno, L. (1974). The $3^{\prime}$ terminal sequence of Escherichia coli $16 \mathrm{~S}$ ribosomal RNA: complementarity to nonsense triplets and ribosomebinding sites. Proceedings of the National Academy of Sciences of the United States of America 71, 13421346.

SteEge, D. A. (1977). $5^{\prime}$ terminal nucleotide sequence of Escherichia coli lactose repressor mRNA : features of translational initiation and reinitiation sites. Proceedings of the National Academy of Sciences of the United States of America 74, 4163-4167.

Stormo, G., SchNeider, T. \& Gold, L. (1982). Characterization of translational initiation sites in E. coli. Nucleic Acids Research 10, 2971-2996.

Twigg, A. J. \& ShERRATT, D. (1980). Trans-complementable copy number mutants of plasmid ColE1. Nature, London 283, 216-218.

Ullman, A. \& Danchin, A. (1980). Role of cyclic AMP in regulatory mechanisms in bacteria. Trends in Biological Sciences 5, 95-96.

Ullman, A., Tillier, F. \& MONOD, J. (1976). Catabolite modulator factor: a possible mediator of catabolite repression in bacteria. Proceedings of the National Academy of Sciences of the United States of America 73, 3476-3479. 